\title{
Effect Of Hyponatremia On Muscle Mass And İnterdialytic Weight Gain İn Haemodialysis Patients
}

\section{Hemodiyaliz Hastalarında Hiponatreminin Kas Kitlesine Ve İnterdiyalitik Kilo Alımına Etkisi}

\author{
Kadir Gökhan Atılgan', Mehmet Deniz Aylı1, Kübra Damla Ekenci², Fevzi Coşkun Sökmen
}

\author{
${ }^{1}$ Dışkapı Yıldırım Beyazıt Eğitim ve Araştırma Hastanesi, Nefroloji Kliniği Ankara/Türkiye \\ ${ }^{2}$ Gazi Üniversitesi Sağlık Bilimleri Enstitüsü Beslenme ve Diyetetik Bölümü Ankara/Türkiye. \\ ${ }^{3}$ Dr Abdurrahman Yurtaslan Ankara Onkoloji Eğitim ve Araştırma Hastanesi Dahiliye Kliniği Ankara/Türkiye
}

Dergiye Ulaşma Tarihi: 18.12.2019 Dergiye Kabul Tarihi: 15.01.2020 Doi: 10.5505/aot.2020.76148

\begin{abstract}
ÖZET
GíRiş ve AMAÇ: Diyaliz öncesi serum sodyum değeri ile malnutrisyon, kas kitlesi, kas fonksiyonu değerlendirme parametreleri ve interdiyalitik kilo alımı arasındaki ilişki değerlendirildi.

YÖNTEM ve GEREÇLER: Kesitsel planlanan çalı̧̧maya 150 hemodiyaliz hastası dahil edildi. Değerlendirmede: malnutrisyon inflamasyon skoru, el kavrama kuvveti, orta üst-kol çevresi, triseps cilt kalınlığı; orta üst-kol kas çevresi, biyoelektiriksel impedans analizi (Yağ yüzdesi, yağsız vücut kitlesi, bazal metabolizma hızı, vücut kitle indeksi, toplam vücut suyu) bakıldı. Aylık bakılan diyaliz giriş SNa'nin altı aylık ortalaması alındı. Hastalar $136.84 \mathrm{mEq} / \mathrm{L}$ olan ortalama serum sodyum değerinin altında: Grup 1 ve üzerinde Grup 2'yi oluşturdu. Serum albümin, C reaktif protein ve diğer aylık rütin laboratuvar tetkikleri hasta dosyasından alındı. İnterdiyalitik kilo alımı: hastanın diyaliz öncesi kilosundan, diyaliz sonrası kilosu çıkarılarak hesaplandı.
\end{abstract}

BULGULAR: Yaş ve cinsiyet uyumlu iki grup arasındaki tek anlamlı fark interdiyalitik kilo alımıydı ( $p<0.001)$. Analizde serum sodyum değeri ile interdiyalitik kilo alımı arasında anlamlı ilişki $(\mathrm{p}<0.001)$ ve ters orantı vardı $(\mathrm{r}=-0.311, \mathrm{p}<0.001)$.

TARTIŞMA ve SONUÇ: Hemodiyaliz hastalarında giriş serum sodyum değeri ile inflamasyon, malnutrisyon, ve antropometrik ölçümlerimiz arasında ilişki bulunamadı. Hemodiyaliz giriş serum sodyum değeri ve interdiyalitik kilo alımı arasında negatif korelasyon vardır ve istatistiksel anlamlıdır.

Anahtar Kelimeler: Hemodiyaliz, hiponatremi, interdiyalitik kilo alımı, kas kitlesi.

ABSTRACT
INTRODUCTION: We evaluated the relationship between the pre-dialytic serum sodium value and malnutrition, the parameters of evaluating the muscular function, muscular mass or interdialytic weight gain.

METHODS: 150 haemodialysis patients were included in the study planned to be cross-sectional. In the evaluation; malnutrition-inflammation score, handgrip strength, mid arm circumference, triceps skinfold, mid arm muscle circumference, and bioelectrical-impedance analysis (fat percent, fat free mass, basal metabolism rate, body mass index, total body water) were considered and examined. The six-month average of the pre-dialytic serum sodium value, which is considered monthly, was taken. The patients under the average value of 136.84 $\mathrm{mEq} / \mathrm{L}$ pre-dialytic serum sodium value were included in the Group 1 and those above it were included in the Group 2. Serum albumin, C-reactive protein and the other monthly routine laboratory examinations were taken from the patient's follow-up file. Interdialytic weight gain was calculated by extracting the patient's post-dialysis weight from the patient's pre-dialytic weight.

RESULTS: The only significant difference between the two groups concordant according to the age and sex was interdialytic weight gain $(\mathrm{p}<0.001)$. In the analysis, there was a significant relationship $(\mathrm{p}<0.001)$ and inverse correlation $(r=-0.311, p<0.001)$ between pre-dialytic serum sodium value and interdialytic weight gain.

DISCUSSION AND CONCLUSION: No relationship was found between the pre-dialytic serum sodium value of the haemodialysis patients and inflammation, malnutrition and anthropometric measurements. There was a negative correlation between the pre-dialytic serum sodium value and interdialytic weight gain, and it was statistically significant.

Adress for correspondence: Ziraat Mahallesi Şehit Ömer Halisdemir Caddesi Dışkapı/altındağ 06610 Ankara - Türkiye

Copyright () Ankara Onkoloji Hastanesi 
Keywords: Haemodialysis, hyponatremia, interdialytic weight gain, muscle mass

\section{GíRIŞ}

Ulusal Sağlık ve Bakım Mükemmelliği Enstitüsü (NICE) malnutrisyonu "enerji, protein, vitamin ve mineral gibi besin eksikliğinin vücut kompozisyonu, fonksiyon veya klinik sonuç üzerinde ölçülebilir olumsuz etkilere neden olduğu bir durum" olarak tanımlamaktadır [1]. Malnutrisyon ciddi bir halk sağlığ1 sorunudur. Diyaliz hastalarında malnutrisyon oranı genel popülasyona ve renal replasman tedavisi almayan kronik böbrek yetmezliği hastalarına göre oldukça yüksektir [2]. Malnutrisyondan korunma için pek çok değerlendirme ölçütü geliştirilmiş ve Uluslararas1 Renal Beslenme ve Metabolizma Derneği (ISRNM) kronik böbrek yetmezliğine bağl malnutrisyonda altta yatan birden fazla nedenin olacağını belirtmiştir [3].

Kardiyovasküler nedenli ölümler ve göstergesi kabul edilen sol ventrikül kitle indeksi, karotis intima media kalınlığı gibi parametrelerle malnutrisyonun ilişkisi çalışmalarda raporlanmıştır [4, 5]. Kardiyovasküler nedenli ve tüm nedenli ölümler serum sodyum dengesizliği ile de gösterilmiştir [6]. Ayrıca hem malnutrisyonun hem de serum sodyum dengesizliğinin inflamatuvar süreçle ilişkili olduğu da gösterilmiştir [7].

Poulikakos ve arkadaşları hemodiyaliz (HD) öncesi düşük serum sodyum değerinin protein enerji kaybı seçilmiş parametreleri ve interdiyalitik kilo alımı (IDKA) ile ilişkili olduğunu belirtmektedir [8]. Bu platformlar 1şığında HD hastalarında pre-diyaliz serum sodyum (SNa) değerinin düşük olması ile malnutrisyon parametreleri, biyoelektiriksel impedans analizi ve İDKA arasinda anlamlı bir ilişkinin olup olmadığını değerlendirdik.

\section{GEREÇ VE YÖNTEM}

Çalışma kesitsel olarak dizayn edildi ve HD tedavi alan 150 hasta dahil edildi. Hiponatreminin sonuçlarını değerlendirebilmek adına hastalar iki grupta incelendi. HD giriş SNa değerinin tüm hastalar için ortalama değeri $136.84 \mathrm{mEq} / \mathrm{L}$ idi. SNa değeri $\leq 136.84 \mathrm{mEq} / \mathrm{L}$ olanlar Grup 1 (hiponatremik grup) ve $\mathrm{SNa}$ değeri $>136.84 \mathrm{mEq} / \mathrm{L}$ olanlar Grup 2 (hiponatremik olmayan grup) hastaları kabul edildi. Çalışma için hastane klinik araştırmalar etik kurulundan onay alınmıştır (Karar tarihi:
10.09.2018 ve karar no: 54/16). Tüm ölçümler ve anketler için hastaların onamları alındı. Katılan hastalar 18 yaşından büyük, diyaliz etkinliğini değerlendirdiğimiz Kt/V değeri $>1.4$ olan ve en az bir yıldır haftada 3 seans, 4 saat HD tedavisi almaktadır. Katılımcılarmdan sadece dört hasta oligürikti. Diğer katılımcilar anürik hastalardı. Amputasyonu, bedensel veya zihinsel engeli olan, çalışma esnasında parenteral nutrisyon desteği alanlar, son bir ay içerisinde cerrahi ya da medikal tedavi amaçlı hastane yatışı olanlar, aktif enfeksiyonu veya romatizmal hastalığı, kanser tanısı olanlar çalışmaya dahil edilmedi. Aylık rütin kan tahlili sonuçları, diyaliz giriş ve çıkış kan basınçları, diyaliz giriş ve çıkış kiloları, eşlik eden hastalıkları hasta dosyalarından kaydedildi. Kan basıncı değerleri HD giriş ve çıkış sistolik kan basıncı (SKB), HD giriş ve çıkış diyastolik kan basınc $(\mathrm{DKB})$ olarak milimetre civa $(\mathrm{mmHg})$ cinsinden kaydedildi. İnterdiyalitik kilo alımı (IDKA): HD giriş kilosundan, HD çıkış kilosu çıkarılarak hesaplandi. Serum sodyum seviyesini belirlemede son altı aya ait diyaliz giriş sodyum değerlerinin ortalaması alındı. İnflamasyonu laboratuvar olarak değerlendirmede serum albümin ve serum Creaktif protein (CRP) düzeyleri kaydedildi. Hastaların antropometrik değerlendirmesinde: orta üst-kol çevresi (OKÇ), triceps cilt kalınlığı (TCK), orta üst-kol kası çevresi (OKKÇ), boy, kilo, vücut kitle indeksi (VKI) ölçülerek veya formülleriyle hesaplanarak kaydedildi. Kas kitlesi ve fonksiyonu için el kavrama kuvveti (EKK), malnutrisyonu değerlendirmek için malnutrisyon inflamasyon skoru anketi (MIS) yapıld1. Biyoelektriksel impedans analizi, malnutrisyon değerlendirme anketi, ve tüm ölçümler aynı beslenme ve diyetetik uzmanı tarafindan yapıldı ve değerlendirildi.

\section{Ölçümler}

Orta üst-kol çevresi: Üst kolda biseps ve triseps kaslarının en geniş olduğu orta noktadan alınan üst kolun çevresidir. $\mathrm{Bu}$ nokta üst kolda acromion çıkıntısı ile humerusun en alt noktası arası mesafenin tam orta noktasıdır. Ölçüm santimetre $(\mathrm{cm})$ cinsinden kaydedilmektedir [9].

Triseps cilt kalınlığl: Triseps cilt kalınlığ ölçümü için cilt kalınlığı ölçüm kaliperi kullanıld1 (Baseline skinfold caliper, 
Fabrication Enterprises Inc. New York, USA). Triseps bölgesinde üst kolun orta noktasında cilt ve cilt altını kavrayacak şekilde iki parmak arasında kalan kısmın kaliper araciyla $\mathrm{cm}$ cinsinden ölçümü ile işlem tamamlandı [9].

Orta üst-kol kast çevresi: OKKÇ= OKÇ (3.1415 x TCK) formülü ile hesaplandı [10].

El kavrama kuvveti testi: El kavrama kuvveti testi için el dinamometresi kullanıldı (TAKEI TKK-5401 digital grip dynamometer, Takei Scientific Instruments Co. Tokyo, Japan). İşlem HD tedavisi sonrası istirahati takiben aktif kolunda HD için arterio-venöz fistül, greft olmayan hastalarda ölçüldü. İşlem için kol ekstansiyon ve adduksiyon pozisyonunda el dinamometresi sıkılarak elde edilen değerin kilogram (kg) cinsinden kaydedilmesidir. Aralıklı olarak $3 \mathrm{kez}$ tekrarlayarak en yüksek elde ettiği değeri hastanın EKK sonucu olarak kaydedildi.

Vücut kitle indeksi: Vücut ağırlı̆̆ / boy ${ }^{2}$ formülü ile hesaplandı ve $\mathrm{kg} / \mathrm{m}^{2}$ olarak kaydedildi.

Malnutrisyon inflamasyon Skoru:

Malnutrisyon inflamasyon skoru anketi; yedisi subjektif global değerlendirme (SGD) anketi sorular1, diğer üçü VKİ, serum albümin ve total demir bağlama kapasitesi değerine göre puanlama yapilan toplam 10 komponentten oluşmaktadır. Her komponentte 0-3 aras1 puanlama yapılmaktadır. Toplamda 0-30 aras1 puanlama yapılmaktadır. Toplam skorun yüksek olması malnutrisyonun şiddetini göstermektedir (1-10 hafif, 11-20 orta, 21-30 arası ağır derece malnutrisyon olarak değerlendirilir).

Biyoelektriksel impedans analizleri: Diyaliz sonras1 hastanın yalın ayak olarak biyoimpedans cihazına yönlendirmelere uyarak çıkması ile cihazın yaptığı ve sonucu kağıt çıktı olarak verdiği işlemdir (TBF-300 body composition analyzer, Tanita Co. Japan). Bu cihaz sayesinde hastanın bazal metabolizma hızı (BMH) kilo kalori (kcal) cinsinden, yağ oranı yüzdesel olarak (\%), yağsız vücut kitlesi (YVK) ve toplam vücut sivisı (TVS) $\mathrm{kg}$ cinsinden raporlanmaktadır.

Kan Basıncı ve kilo değerlerinde hassas olmak için hastanın antropometrik ölçümlerinin yapıldığ1 haftadaki 3 seansın ortalamaları alındı. Ardışık 3 seansta saatlik ölçülen SKB ve DKB değerlerinin ortalaması alındı. Aynı şekilde Ardışık 3 seans diyaliz giriş tartı değerlerinin ortalaması ve çıkış tartılarının ortalamas1 kg cinsinden kaydedildi.

\section{İstatistiksel Analiz}

Tanımlayıcı istatistik sonuçları ortalama \pm standart sapma ile sunuldu. Tüm değişkenlerin normalitesini değerlendirmek için ShapiroWilk testi uyguland. Normal dağılımlı değişkenler için Independent-Samples $t$ test uyguland1. Korelasyonun değerlendirmesinde Pearson korelasyon analizi kullanıldı. Kategorik değişkenlerin istatistiğ $\mathrm{Ki}$ kare analizi, sonuç değerlendirmesi Pearson veya Fischer-Exact test ile yapıldı. İstatistikler için Statistical Package for Social Sciences for Windows version 25.0 (SPSS Inc, Chicago, IL, USA) kullanıldı. İstatistiksel anlamlılık için $\mathrm{p}$ değeri $<0.05$ kabul edildi.

\section{SONUÇLAR}

Ortalama HD giriş SNa değeri olan 136.84 $\mathrm{mEq} / \mathrm{L}$ değerine göre Grup 1 ve Grup 2'ye ait yaş, cinsiyet, diyabet (DM), hipertansiyon (HT) klinik ve laboratuvar ölçüm değerleri Tablo 1 'de gösterilmiştir. Grup 1 ve Grup 2 arasında yaş $(60.0 \pm 11.24$ ve $61.13 \pm 14.34)$ ve cinsiyet (Kadın \%52.9 ve \%52.1) eşleşmesi vardı $(\mathrm{p}=$ 0.610 ve $p=0.699$ sirasiyla). Grup 1 ve Grup 2'de DM hasta sayıs1: 23 (\%33.8) ve 19 (\%23.2) $(\mathrm{p}=0.132)$, HT hasta sayıs1 $41(\% 60.3)$ ve 43 $(\% 52.4)(\mathrm{p}=0.550)$ idi. Buna göre gruplar arasında tek anlamlı fark IDKA değeri ile gösterilebilmiştir (2539.85 \pm 907.42 ve 1960.14 \pm 880.15 [p $<0.001]$ ). Serum albümin, CRP, HD giriş ve çıkış SKB ve DKB değerleri, biyoimpedans ölçümleri (BMH, yağ oranı, TVS, YVK), VKİ, OKÇ, TCK, OKKÇ, MİS ve EKK değerleri ile hiponatremik ve hiponatremik olmayan HD hastaları arasında anlamlı fark bulunamadı ( $\mathrm{p}>0.05$ tüm değerler için). Katılımcılardan 12 hastada orta derecede malnutrisyon (12.41 \pm 0.34$)$ vard1. Diğer hastalar hafif derece malnutrisyon $(6.25 \pm 2.26)$ olarak bulundu. Ağır derece malnutrisyonu olan hastamız yoktu. Malnutrisyon derecesine göre kategorik sinıflandırma yaptığımızda (hafif derece 1 , orta derece malnutrisyon 2), orta derece malnutrisyonu olan 12 hastanın $\mathrm{SNa}$ değeri $135.33 \pm 2.67$ iken hafif derece malnutrisyonu olan hastalarımız için $\mathrm{SNa}$ değeri $138.18 \pm 2.72$ olarak bulundu $(\mathrm{p}=$ 0.002 ). Korelasyon analizi değerlendirmesinde $\mathrm{HD}$ giriş $\mathrm{SNa}$ değeri ile İDKA negatif korelasyon göstermiştir $(r=-0.311, p<0.001)$. Serum sodyum değeri ile MİS $(r=-0.213$ ve $\mathrm{p}=$ 
0.10) negatif korele idi ama anlamlı değildi. Yukarıda bahsettiğimiz geriye kalan tüm parametrelerle HD giriş $\mathrm{SNa}$ değeri arasında korelasyon saptanmamıştır.

İnterdiyalitik kilo alımı: yaş ile negatif korelasyon $(\mathrm{r}=-0.222, \mathrm{p}=0.011)$, EKK ile pozitif korelasyon $(\mathrm{r}=0.217, \mathrm{p}=0.013)$ göstermiştir.

Orta üst-kol kas çevresi: HD giriş SKB ile pozitif korelasyon $(\mathrm{r}=0.235, \mathrm{p}=0.018)$, MIS ile negatif korelasyon $(r=-0.720, p=0.001)$, albümin ile pozitif korelasyon $(\mathrm{r}=0.260, \mathrm{p}=$ $0.009)$, boy ile pozitif korelasyon $(\mathrm{r}=0.207, \mathrm{p}$ $=0.04)$, kilo ile pozitif korelasyon $(\mathrm{r}=0.517, \mathrm{p}$
$=0.001)$, VKİ ile pozitif korelasyon $(\mathrm{r}=0.432$, $\mathrm{p}=0.001), \mathrm{BMH}$ ile pozitif korelasyon $(\mathrm{r}=$ $0.440, \mathrm{p}=0.001)$, yağ oran1 ile pozitif korelasyon $(\mathrm{r}=0.296, \mathrm{p}=0.007)$, TVS ile pozitif korelasyon $(r=0.3, p=0.003)$, FFM ile pozitif korelasyon $(\mathrm{r}=0.31, \mathrm{p}=0.005)$, EKK ile pozitif korelasyon $(\mathrm{r}=0.22, \mathrm{p}=0.034)$ göstermiştir.

Hasta yaş1 : CRP ile pozitif korelasyon $(\mathrm{r}=$ $0.180, p=0.038)$, BMH ile negatif korelasyon $(\mathrm{r}=-0.190, \mathrm{p}=0.041)$, yağ oranı ile pozitif korelasyon $(\mathrm{r}=0.394, \mathrm{p}=0.001)$, EKK ile negatif korelasyon $(\mathrm{r}=-0.296, \mathrm{p}=0.001)$ göstermiştir.

Tablo 1: Gruplara ait laboratuvar, ölçüm ve klinik verileri.

\begin{tabular}{|c|c|c|c|}
\hline & $\begin{array}{l}\text { Grup } 1 \\
(\mathrm{SNa} \leq 136.84 \mathrm{mEq} / \mathrm{L})\end{array}$ & $\begin{array}{l}\text { Grup } 2 \\
(\mathrm{SNa}>136.84 \mathrm{mEq} / \mathrm{L})\end{array}$ & $p$ değeri \\
\hline Hasta sayısı n (\%) & $68(\% 44.7)$ & $82(\% 55.3)$ & \\
\hline Yaş (yıl) & $60.0 \pm 11.24$ & $61.13 \pm 14.34$ & 0.610 \\
\hline Kadın n (\%) & $36(\% 52.9)$ & $46(\% 52.1)$ & 0.699 \\
\hline Erkek n (\%) & $32(\% 47.1)$ & $36(\% 43.19)$ & 0.699 \\
\hline HD süresi (ay) & $43.82 \pm 21.97$ & $44.04 \pm 25.59$ & 0.958 \\
\hline Giriş SKB (mmHg) & $135.07 \pm 16.82$ & $133.20 \pm 19.10$ & 0.528 \\
\hline Giriş DKB (mmHg) & $78.07 \pm 9.46$ & $79.07 \pm 9.20$ & 0.514 \\
\hline Çıkış SKB (mmHg) & $121.93 \pm 15.56$ & $119.77 \pm 18.93$ & 0.453 \\
\hline Çıkış DKB (mmHg) & $73.15 \pm 7.32$ & $72.52 \pm 9.58$ & 0.661 \\
\hline İDKA (mg) & $2539.85 \pm 907.42$ & $1960.14 \pm 880.15$ & $<0.001$ \\
\hline Mis & $8.09 \pm 4.24$ & $7.10 \pm 2.49$ & 0.255 \\
\hline $\mathrm{SNa}(\mathrm{mEq} / \mathrm{L})$ & $134.81 \pm 1.81$ & $138.88 \pm 1.92$ & \\
\hline CRP (mg/L) & $16.55 \pm 19.89$ & $17.61 \pm 19.90$ & 0.750 \\
\hline Albumin $(\mathrm{g} / \mathrm{L})$ & $4.00 \pm 0.49$ & $3.98 \pm 0.36$ & 0.673 \\
\hline DM n $(\%)$ & $23(\% 33.8)$ & $19(\% 23.2)$ & 0.132 \\
\hline HT n $(\%)$ & $41(\% 60.3)$ & $43(\% 52.4)$ & 0.550 \\
\hline Boy $(\mathrm{cm})$ & $163.45 \pm 8.33$ & $162.26 \pm 9.78$ & 0.433 \\
\hline Kilo (kg) & $70.60 \pm 16.26$ & $65.90 \pm 13.22$ & 0.050 \\
\hline VKİ $\left(\mathrm{kg} / \mathrm{m}^{2}\right)$ & $26.34 \pm 5.59$ & $25.35 \pm 5.20$ & 0.267 \\
\hline BMH (kcal) & $1393.97 \pm 234.02$ & $1369.12 \pm 189.40$ & 0.512 \\
\hline Yağ oranı (\%) & $29.95 \pm 11.51$ & $27.18 \pm 10.02$ & 0.149 \\
\hline TVS (kg) & $35.39 \pm 7.87$ & $35.30 \pm 6.71$ & 0.849 \\
\hline YVK $(\mathrm{kg})$ & $48.34 \pm 10.74$ & $47.49 \pm 9.90$ & 0.578 \\
\hline EKK (kg) & $19.04 \pm 7.38$ & $18.60 \pm 8.38$ & 0.731 \\
\hline OKÇ (cm) & $27.97 \pm 4.36$ & $27.33 \pm 3.84$ & 0.351 \\
\hline TCK $(\mathrm{cm})$ & $2.51 \pm 0.93$ & $2.56 \pm 1.39$ & 0.834 \\
\hline OKKÇ (cm) & $20.04 \pm 2.60$ & $20.10 \pm 3.10$ & 0.949 \\
\hline
\end{tabular}


*Independent samples $t$ test uygulandı ve $p$ değeri $<0.05$ anlamlı olarak değerlendirildi. Tüm değerler ortalama \pm standart sapma olarak verildi. HD: Hemodiyaliz, SKB: Sistolik kan basıncı, DKB: Diastolik kan basınc1, IDKA: interdiyalitik kilo alımı, MIS: Malnutrisyon inflamasyon skoru, SNa: Serum sodyum değeri, CRP: C-reaktif protein, DM: Diabetes mellitus, HT: Hipertansiyon, VKİ: Vücut kitle indeksi, BMH: Bazal metabolizma hızı, TVS: Toplam vücut sıvısı, YVK: Yağsız vücut kitlesi, EKK: El kavrama kuvveti, OKÇ: orta kol çevresi, TCK: Triceps cilt kalınlığı, OKKÇ: Orta kol çevresi.

Malnutrisyon inflamasyon skoru: Albümin $(\mathrm{r}=$ $-0.40, \mathrm{p}=0.001)$, ağırlık $(\mathrm{r}=-0.317, \mathrm{p}=0.01)$, $\mathrm{BMH}(\mathrm{r}=-0.318, \mathrm{p}=0.014)$, YVK $(\mathrm{r}=-0.292$ $, p=0.020)$, TVS $(r=-0.294, p=0.020)$, EKK $(\mathrm{r}=-0.273, \mathrm{p}=0.04)$, OKKÇ $(\mathrm{r}=-0.720, \mathrm{p}=$ $0.001)$ ile istatistiksel olarak anlaml ve negatif korele idi.

\section{TARTIŞMA}

Kronik böbrek yetmezliğinde glomerüler filtrasyon hızı ve idrar miktarı azaldıkça hiponatremi görülme oranı artmaktadır. Hemodiyaliz hastalarında $\mathrm{HD}$ giriş $\mathrm{SNa}$ değerine göre hiponatremi ile başta kardiyovasküler nedenli olmak üzere ölüm arasında ilişki olduğu rapor edilmektedir. Kabul edilen ilişkinin net bir açılaması yapılamamıştır. Konuyu ilgi çekici yapan ve bizimde bu çalışmayı planlamaya yönlendiren hiponatremi ile kas kitlesi arasında ilişkiyi düşündüren ilk varsayım: Serum sodyumun sinir iletiminde, kas aksiyon potansiyeli oluşumunda, hücre fonksiyonlarının devamlılığını sağlayan transmembran elektriksel gradiyenti sağlamasıdır. $\mathrm{Bu}$ varsayımın beyin fonksiyonlarına etkisi gösterilmiş olsa da diğer organ fonksiyonları için halen bilinmezliğini korumaktadır [11].

İkinci varsayım: Oligoanürik HD hastalarında hiponatremi gelişimi; tuz kısıtlı diyet ya da serbest su alımının artışı ile mümkündür. Davranışsal düzenleme ağırlıklı kabul edilen varsayımdır [12]. Bununla birlikte HD hastalarında artmış renin anjiotensin sistemi aktivasyonu ve artmış anjiotensin-II kan düzeyinin polidipsi yapıcı etkisinin olduğu bilinmektedir [13]. Anjiotensin-II ile neden olduğu artmış reaktif oksijen radikalleri üzerinden kas kaybına neden olduğu gösterilmiştir [14]. Yakın dönem hayvan çalışmasında anjiotensin-II tip-1 reseptör antagonisti ile myokardial disfonksiyonun önlenebileceğini göstermiştir [15].

Üçüncü varsayım: Erken dönem çalışmalarında hiponatremi ve kas kaybında ortak paydanın inflamasyon olduğu fikri hakim görüştü. İnflamasyonda ve yaşl1lıkta interlökin-6 üzerinden ozmotik olmayan arjinin vazopressin salınımı ile hiponatremi gelişebileceği rapor edilmiştir [16]. Çalışmadaki hastaların HD sürelerini göz önüne aldığımızda büyük çoğunluğun anürik olduğunu ve renal su tutulumunun olamayacağını bildiğimize göre $\mathrm{bu}$ hipotezin çokta uygun olmadığını düşünmekteyiz.

Yakın dönemde HD hastalarında hiponatremi, protein enerji kaybı arasında ilişkiyi değerlendirmek üzere sadece bir çalışma yapıldı. Poulikakos ve arkadaşlarının yaptı̆ğ bu çalışmada HD öncesi SNa değeri ile OKKÇ, EKK ve SGD'nin pozitif korele olduğunu, SNa değerinin IDKA ile negatif korelasyon gösterdiğini ama CRP ve albümin ile korelasyonun olmadığını ifade etmektedir. Bununla birlikte CRP, yaş, cinsiyet ve DM yönünden parsiyel korelasyon yaptıklarında ise $\mathrm{SNa}$ ile OKKÇ ve EKK ile korelasyonun kalmadığını, sadece SGD ile ilişkinin devam ettiğini rapor etmektedirler [8].

Çalışmamızı bu hipotezlerin ve çalışmaların 1şığında gerçekleştirdiğimizde $\mathrm{HD}$ öncesi $\mathrm{SNa}$ sadece IDKA ile ilişkili olup, negatif korelasyon göstermekteydi. $\mathrm{SNa}$ değeri ile CRP, albümin arasında ilişki saptanmaması; HD hastalarında hiponatreminin, inflamasyonla açıklanamayacağını gösterdi. Malnutrisyon için değerlendirdiğimiz MíS ile HD giriş SNa değeri ile anlamlı ilişki bulunamasa da MIS için HD hastalarını kategorize ettiğimizde anlamlı bir ilişki olmakla birlikte anlamlı korelasyon gösterilemedi. Muhtemelen hasta seçme kriterlerimizde sonuçların net olması adına düşkün ve ampute hastaları dahil etmemiş olmamız, ağırlıklı olarak hafif derece malnutrisyonlu hastaların olması bunda etkili olmaktadır. Malnutrisyon ile $\mathrm{HD}$ giriş $\mathrm{SNa}$ değeri arasında ilişki bulamamamızın bir diğer muhtemel nedeni beslenme değerlendirmesi için sübjektif global değerlendirme yerine inflamasyon belirteçlerininde bulunduğu Mís anketini kullanmamızdır. Ayrıca çalışmamızda biyoimpedans analizi ile kas kitlesi değişimi konusunda objektif olarakta değerlendirmiş olduk. Biyoimpedans analiz sonuçları ile de 
$\mathrm{SNa}$ değeri arasında korelasyon yoktu ve her iki grup arasında anlamlı farklılık tespit edilmedi. Her iki grup HD hastalarında ölçümler sonucunda inflamasyon, malnutrisyon mevcut iken kas kaybı çok az düzeydeydi (Tablo 1). Bu durumda HD hastalarında hiponatremiyi izah edecek ilk tablo susama hissidir. Bunda osmolar dalgalanmanın etkisini ön planda tutmak gerekmektedir. Rütin olarak yapılan ve hastanın diyaliz konforunu sağlamayı amaçlayan diyalizat sodyum değerinin (DNa) $140 \mathrm{mEg} / \mathrm{L}$ olarak sabit kalması veya yükseltilmesi hiponatremik hastada siklik osmolar düzensizliğe ve artan susama hissi ile IDKA artışına neden olmaktadır [17]. Düşük DNa değerinin sonuçlarının değerlendirildiği 2019 y1l sistematik derlemesinde Dunlop ve arkadaşları: düşük $\mathrm{DNa}$ ile İDKA ve kan basınçlarının azalacağını belirtmişlerdir [18]. $\mathrm{Bu}$ durumda da intradiyalitik hipotansiyona ve düşük $\mathrm{SNa}$ değerlerine neden olunabileceğini ve sonuç olarak ölüm riskini artıracağını göz önünde bulundurmak gerektiğini savunmaktadırlar.

Çalışmamızda IDKA ile yaşın negatif korelasyonu ve EKK'nin pozitif korelasyonu olduğunu gördük. Ayrıca yaş ve EKK'nin negatif korele olduğunu belirtmiştik. E1 kavrama kuvveti testi hem kas kitlesini gösteren hem de malnutrisyon değerlendirmede değerli bir testtir. MiS ile negatif korele olarak çalışmamızda da teyid edildi. İnterdiyalitik kilo alımı için Ipema ve arkadaşlarının 138 HD hastası ile yaptı̆̆ 1 çalışmada yaş, boy, kilo ve diürezin etkili olduğunu belirtmişlerdir [19]. Alternatif olarak protein enerji kaybı tablosunda hücre içi solütler olan potasyum ve inorganik fosfatın azalması söz konusu olacaktır. Böyle bir durumda rezidüel renal fonksiyon yokluğunda veya vazopressin varlığında sodyum hücre içine yer değiştirecektir [20]. Sonuç yine hiponatremik artmış vücut sıvısı olacaktır.

Direkt olarak SNa değeri ile MİS ilişkisini tespit edememiş olsak da MİS değerlerini kategorik değerlere çevirdiğimizde malnutrisyonla $\mathrm{SNa}$ değeri ilişkili bulunmaktadır. Yakın dönem çalışmalarda protein enerji kaybı tablosu ile hiponatremi arasındaki ilişkiyi diyaliz hastalarında göstermişlerdir [7, 20].

van Dronkelaar sistematik derlemesinde; minerallerin genel popülasyonda sarkopeni üzerine etkilerini değerlendirmiştir. Buna göre gözlemsel çalışmalarda selenyum ve kalsiyum alımının kas kitlesi ile ilişkili olduğunu, ayrıca magnezyum, selenyum, demir ve çinko alımının yaşlılarda fiziksel performansı artırmada etkili olduğunu savunmaktadır. Çalışmaları olmadığı için sodyum ve potasyum alımı için bu olumlu etkilerden bahsetmenin mümkün olmadığını belirtmiştir [21].

Poulikakos'un çalışmasındaki hiponatremik grubun yaş ortalaması, DM varlığı ve kadın sayısı, hiponatremik olmayan gruba göre daha fazlaydı. Buna bağlı olarak hastaların OKKÇ, EKK ve SGD değerleri hiponatremik grupta anlamlı olarak düşük olarak sonuçlanmaktadır. Çalışmamız sonuçları Poulikakos'un parsiyel korelasyon analizi sonuçları ile değerlendirdiğimizde uyumlu görülmektedir. Bizim korelasyon sonuçlarımızda OKKÇ malnutrisyon ve inflamasyonla ilişkili iken, IDKA hiponatremi, yaş ve malnutrisyondan etkilenmektedir.

\section{Çıkarım}

Hemodiyaliz hastalarında hiponatremi ile mortalite arasında ilişki varlığı rapor edilmiş olmasına rağmen halen tartışmalı konudur. Sodyum düzeyinin genel popülasyon da dahil kas kitlesi ve kas fonksiyonlarına etkin olması konusunda yeterli bilgi bulunmamaktadır. Yaş, cinsiyet, HD süresi, eşlik eden hastalıklar açısından uyumlu hiponatremik ve hiponatremik olmayan hastaları karşılaştırdığımız kesitsel çalışmamızda HD giriş $\mathrm{SNa}$ değeri düşük grupta sadece İDKA ile istatistiksel anlamlilık ve negatif korelasyon mevcut idi. Çalışmamız HD hastalarında SNa değeri ile malnutrisyon ve kas kitlesi arasında ilişkinin değerlendirildiği ikinci çalışmadır. Ölçümlerin güvenirliliği ve güçlü olması adına biyoelektriksel impedans analizi ilave edilmiştir. Katılımcı sayısının azlığı çalışmanın limitasyonudur.

\section{Teşekkür}

Yazarlar çalışmada çıkar çatışması, finansal destek veya bağış olmadığını kabul ve beyan etmektedir. İngilizce özetin değerlendirme ve düzenlenmesi Hacı Bayram-1 Veli Üniversitesi İngiliz Dili ve Edebiyatı öğretim üyesi Doktor öğretim üyesi Yavuz Çelik tarafından yapılmıştır.

\section{REFERANSLAR}

1. National Collaborating Centre for Acute C: National Institute for Health and Clinical Excellence: 
Guidance. In: Nutrition Support for Adults: Oral Nutrition Support, Enteral Tube Feeding and Parenteral Nutrition. edn. London: National Collaborating Centre for Acute Care (UK) National Collaborating Centre for Acute Care.; 2006.

2. Wright M, Southcott E, MacLaughlin H, Wineberg $\mathrm{S}$. Clinical practice guideline on undernutrition in chronic kidney disease. BMC Nephrol 2019, 20(1):370.

3. Fouque D, Kalantar-Zadeh K, Kopple J, et al. A proposed nomenclature and diagnostic criteria for protein-energy wasting in acute and chronic kidney disease. Kidney Int 2008, 73(4):391-398.

4. An WS, Son YK. Vascular calcification on plain radiographs is associated with carotid intima media thickness, malnutrition and cardiovascular events in dialysis patients: a prospective observational study. BMC Nephrol 2013, 14:27.

5. Maruyama K, Nakagawa N, Saito E, et al. Malnutrition, renal dysfunction and left ventricular hypertrophy synergistically increase the long-term incidence of cardiovascular events. Hypertens Res 2016, 39(9):633-639.

6. Rhee CM, Ravel VA, Ayus JC, et al. Pre-dialysis serum sodium and mortality in a national incident hemodialysis cohort. Nephrol Dial Transplant 2016, 31(6):992-1001.

7. Dekker MJ, Marcelli D, Canaud B, et al. Unraveling the relationship between mortality, hyponatremia, inflammation and malnutrition in hemodialysis patients: results from the international MONDO initiative. Eur J Clin Nutr 2016 , 70(7):779-784.

8. Poulikakos D, Marks V, Lelos N, Banerjee D. Low serum sodium is associated with protein energy wasting and increased interdialytic weight gain in haemodialysis patients. Clin Kidney J 2014, 7(2):156-160.

9. Bishop CW, Bowen PE, Ritchey SJ. Norms for nutritional assessment of American adults by upper arm anthropometry. Am J Clin Nutr 1981, 34(11):2530-2539.

10. Tartari RF, Ulbrich-Kulczynski JM, Filho AFF. Measurement of mid-arm muscle circumference and prognosis in stage IV non-small cell lung cancer patients. Oncol Lett 2013, 5(3):1063-1067.

11. Renneboog B, Musch W, Vandemergel X, Manto MU, Decaux G. Mild chronic hyponatremia is associated with falls, unsteadiness, and attention deficits. Am J Med 2006, 119(1):71.e71-78.
12. Bellomo G, Coccetta P, Pasticci F, Rossi D, Selvi A. The Effect of Psychological Intervention on Thirst and Interdialytic Weight Gain in Patients on Chronic Hemodialysis: A Randomized Controlled Trial. J Ren Nutr 2015, 25(5):426-432.

13. Graziani G, Badalamenti S, Del Bo A, et al. Abnormal hemodynamics and elevated angiotensin II plasma levels in polydipsic patients on regular hemodialysis treatment. Kidney Int 1993, 44(1):107114.

14. Sukhanov S, Semprun-Prieto L, Yoshida T, et al. Angiotensin II, oxidative stress and skeletal muscle wasting. Am J Med Sci 2011, 342(2):143-147.

15. Liang L, Yuan W, Qu L, et al. Administration of losartan preserves cardiomyocyte size and prevents myocardial dysfunction in tail-suspended mice by inhibiting p47(phox) phosphorylation, NADPH oxidase activation and MuRF1 expression. J Transl Med 2019, 17(1):279.

16. Swart RM, Hoorn EJ, Betjes MG, Zietse R. Hyponatremia and inflammation: the emerging role of interleukin-6 in osmoregulation. Nephron Physiol 2011, 118(2):45-51.

17. Santos SF, Peixoto AJ. Revisiting the dialysate sodium prescription as a tool for better blood pressure and interdialytic weight gain management in hemodialysis patients. Clin J Am Soc Nephrol 2008, 3(2):522-530.

18. Dunlop JL, Vandal AC, Marshall MR. Low dialysate sodium levels for chronic haemodialysis Cochrane Database Syst Rev 2019, 1:Cd011204.

19. Ipema KJ, Kuipers J, Westerhuis R, et al. Causes and Consequences of Interdialytic weight gain. Kidney Blood Press Res 2016, 41(5):710-720.

20. Rhee CM, Ayus JC, Kalantar-Zadeh K. Hyponatremia in the Dialysis Population. KidneyInt Rep 2019, 4(6):769-780.

21. van Dronkelaar C, van Velzen A, Abdelrazek M, van der Steen A, Weijs PJM, Tieland M. Minerals and Sarcopenia; The Role of Calcium, Iron, Magnesium, Phosphorus, Potassium, Selenium, Sodium, and Zinc on Muscle Mass, Muscle Strength, and Physical Performance in Older Adults: A Systematic Review. J Am Med Dir Assoc 2018, 19(1):6-11.e13. 